\title{
Soft tissue Rosai-Dorfman disease of the posterior mediastinum $* * *$
}

\author{
Doença de Rosai-Dorfman de partes moles no mediastino posterior
}

\author{
Antônio Luiz Penna Costa, Natália Oliveira e Silva, Marina Pamponet Motta, \\ Rodrigo Abensur Athanazio, Daniel Abensur Athanazio, Paulo Roberto Fontes Athanazio
}

\begin{abstract}
Rosai-Dorfman disease (RDD) consists of sinus histiocytosis with massive lymphadenopathy. Extranodal involvement occurs in up to $43 \%$ of cases. However, isolated soft tissue RDD is rare. lsolated mediastinal RDD is exceedingly rare, and there have been only three previous reports. Involvement of the posterior mediastinum in RDD has been reported only in the context of disseminated RDD. Here, we report the case of a 49-year-old female patient with a two-year history of cervical pain and lymphadenomegaly, which resolved spontaneously. A CT scan revealed a left paravertebral mass with a diameter of $6 \mathrm{~cm}$. The patient was submitted to surgical excision of the mass. Microscopic examination and immunophenotyping of the surgical specimen led to a diagnosis of RDD. During a 12-month follow-up period, the patient complained of mild cough and chest pain. Periodic imaging tests showed no sign of recurrence, and no postoperative cervical lymphadenomegaly was detected.
\end{abstract}

Keywords: Histiocytosis, sinus; Soft tissue neoplasms; Mediastinal neoplasms; Mediastinum.

\section{Resumo}

A doença de Rosai-Dorfman (DRD) consiste em histiocitose sinusal com linfadenopatia maciça. 0 envolvimento extranodal ocorre em até 43\% dos casos. Entretanto, a DRD de partes moles de forma isolada é rara. A forma isolada de DRD mediastinal é muito rara, com apenas três relatos prévios. 0 envolvimento do mediastino posterior só foi descrito no contexto da DRD disseminada. Relatamos o caso de uma paciente de 49 anos de idade com história de dor e linfadenomegalia cervical há dois anos, com resolução espontânea. A TC revelou uma massa paravertebral à esquerda medindo $6 \mathrm{~cm}$ de diâmetro. A paciente foi submetida à ressecção cirúrgica da massa. 0 exame microscópico e estudo do imunofenótipo da peça cirúrgica definiram o diagnóstico de DRD. A paciente foi acompanhada por 12 meses, queixando-se de tosse discreta e dor torácica. 0 acompanhamento por imagem não detectou recorrência, e nenhuma linfadenomegalia cervical foi observada após a cirurgia.

Descritores: Histiocitose sinus; Neoplasias de tecidos moles; Neoplasias do mediastino; Mediastino.

\section{Introduction}

Rosai-Dorfman disease (RDD), or sinus histiocytosis with massive lymphadenopathy, is characterized by massive painless bilateral lymphadenomegaly that typically involves the lymph node stations of the head and neck. The typical presentation includes fever, leukocytosis, elevated erythrocyte sedimentation rate and polyclonal hypergammaglobulinemia. Most cases occur in the first two decades of life, although any age group can be affected. The classical morphological profile is of an inflam- matory infiltrate rich in lymphocytes, plasma cells and large histiocytes, the last occasionally presenting emperipolesis, which is the hallmark of the disease. ${ }^{(1)}$ Emperipolesis is defined as the active penetration by one cell into and through a larger cell, which, in the case of RDD, manifests as mature lymphocytes within the cytoplasm of large histiocytes.

Extranodal involvement in RDD has been reported in a wide range of organs, the skin and nasal sinuses being the organs most often

\footnotetext{
* Study carried out at the Hospital Espanhol, Universidade Federal da Bahia, Salvador, Brazil.

Correspondence to: Daniel Abensur Athanazio. Departamento de Biointeração, ICS-UFBA, Av. Reitor Miguel Calmon, s/nº, Campus do Canela, CEP 40110-100, Salvador, BA, Brasil.

Tel 5571 3245-8602.Fax 5571 3240-4194.E-mail: daa@ufba.br or daniel_fiocruz@hotmail.com

Financial support: None.

Submitted: 13 October 2008. Accepted, after review: 29 December 2008.

** A versão completa em português deste artigo está disponível em www.jornaldepneumologia.com.br
} 
affected. In the largest study of RDD, 182 (43\%) of the 423 patients evaluated had extranodal disease, whereas only $13(3 \%)$ presented the typical morphological profile of soft tissue RDD without detectable lymphadenopathy. ${ }^{(2)}$ The nodal form of the disease is classified as an inflammatory/hyperplasic disorder that typically undergoes spontaneous regression, whereas the natural history of extranodal RDD is associated with indolent growth and recurrence after years or decades. Therefore, soft tissue RDD has been recognized as a distinct clinicopathologic entity. ${ }^{(2,3)}$ lsolated mediastinal RDD is exceedingly rare, and there have been only three previous reports, which were interpreted as follows: bilateral hilar lymphadenopathy ${ }^{(1)}$; primary thymic involvement ${ }^{(4)}$; and extranodal disease in anterior mediastinum. ${ }^{(5)}$ Involvement of the posterior mediastinum in RDD has been reported only in the context of disseminated RDD. ${ }^{(6)}$

\section{Case report}

A 49-year-old female patient, who was a heavy smoker for 30 years (30 pack-years) and had chronic cough, sought medical assistance due to dyspnea and chest pain for 2 years. She was HIV negative. Her medical history included having been treated for pulmonary TB (4 years prior) and recurrent pneumonia (4 episodes in the last 4 years), as well as neck pain and lymphadenomegaly (2 years prior, with spontaneous resolution). A CT scan, without contrast enhancement, revealed a left paravertebral mass (diameter, $6.0 \mathrm{~cm}$ ), located in the posterior mediastinum (Figure 1), and showed that the lungs were clear. The lesion was in close proximity to the descending aorta and bone structures, without signs of invasive growth. The patient was submitted to surgical excision of the mass. The surgical specimens included a $5.0-\mathrm{cm}$ yellowish fragment and a $1.5-\mathrm{cm}$ white nodule (identified as a para-aortic lymph node), together with lymph nodes from the left hilum and pulmonary ligament. Microscopically, the larger fragment and the para-aortic lymph node exhibited fibrous and adipose tissue, together with chronic inflammatory infiltrate in which there was a predominance of mature lymphocytes and plasma cells. Large histiocytes with pale cytoplasm were a common finding, as were sparse areas of aggregation and images suggestive of emperipolesis (Figure 2a). These initial findings were suggestive of a diagnosis of RDD, and immunohistochemistry was recommended for confirmation. The immunohistochemical procedures were performed at a referral laboratory and supported this diagnosis, based on the analysis of the large histiocytes, in which we observed expression of S-100 (Figure 2b) and CD68, although no CD1a reactivity was detected. Kappa and lambda chains were expressed in plasma cells, whereas CD20 and CD3 were expressed in mature lymphocytes. There was no residual lymphoid tissue in the largest fragment or in the para-aortic nodule. The lymph nodes resected from the left hilum and pulmonary ligament were unaffected. No additional treatment was administered after surgery. During a 12-month follow-up period, the patient complained of mild cough and chest pain. Periodic imaging tests showed no sign of recurrence, and no postoperative cervical
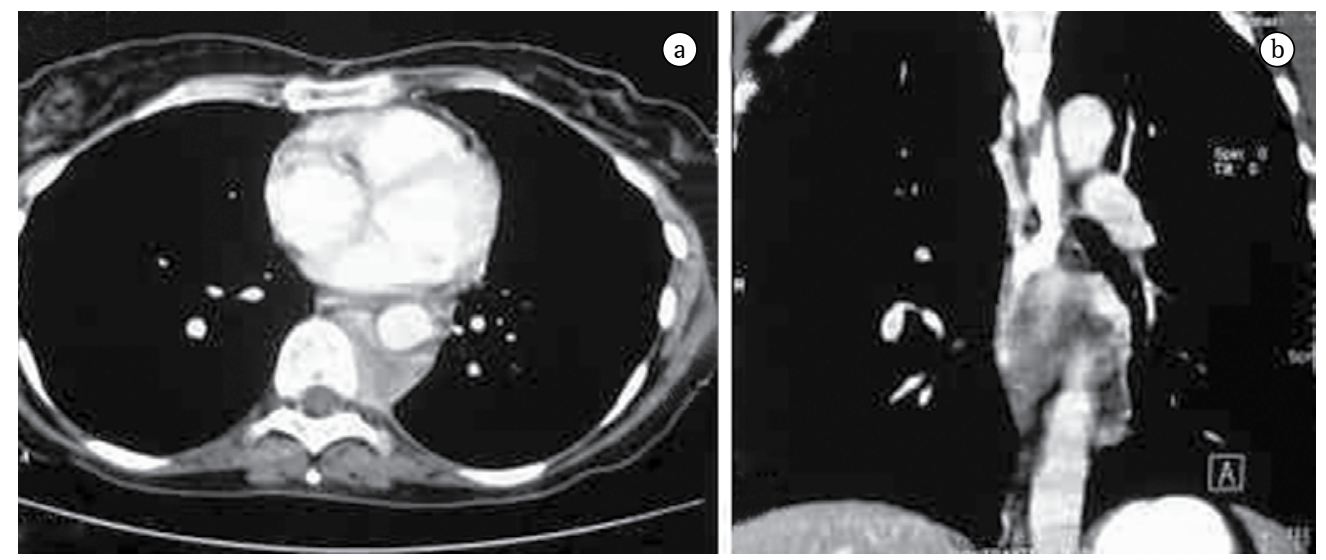

Figure 1 - Left paravertebral mass in the posterior mediastinum: a) axial image; b) reconstruction (coronal) image. 

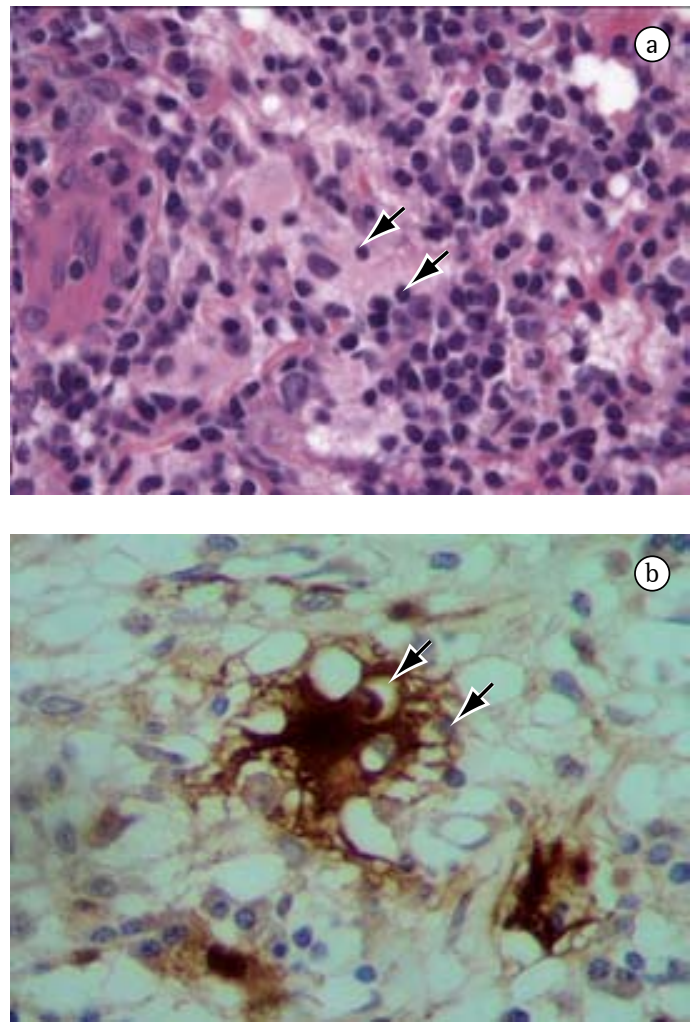

Figure 2 - (a) Two foci of emperipolesis (hematoxylin $\&$ eosin; magnification, $\times 1,000$ ); and (b) S-100 expression in large histiocytes (anti-S100 antibody, streptavidin-peroxidase conjugate; magnification, $\times 1,000$; white arrows indicate lymphocytes within the cytoplasm of large histiocytes).

lymphadenomegaly was detected. Pulmonary function tests (spirometry) performed at the time of tumor diagnosis and six months after tumor removal revealed a mild restrictive pattern.

\section{Discussion}

lsolated extranodal RDD of soft tissues is rare. In the largest study of RDD, 13 (3\%) of the 423 patients presented soft tissue RDD without detectable lymph node involvement. ${ }^{(2)}$ A retrospective study conducted by the United States Armed Forces Institute of Pathology described 17 cases of soft tissue RDD, 13 of which did not present lymphadenopathy. ${ }^{(3)}$ The typical clinical and pathological presentation is of a slow-growing, painless, non-tender mass in which the histological findings can be less specific than those obtained for the corresponding lymph nodes. Fusiform histiocytes, a vague storiform pattern, deposits of thin collagen fibers and inconspicuous emperipolesis have all been reported in soft tissue RDD. ${ }^{(2,3)}$ The diagnosis of RDD is based on routine staining, although immunohistochemistry can be useful in less specific morphological profiles. Reactivity of S-100 protein and histiocytic/lysosomal markers (CD68, lysozyme, alpha-1 antitrypsin and alpha- 1 antichymotrypsin) are common features but are not required for diagnostic confirmation..$^{(3)}$ In the present report, we have described the case of a 49-year-old woman with soft tissue RDD in the posterior mediastinum, without lymph node disease or involvement of any other organ.

In regard to its natural behavior, soft tissue RDD has been described as a slow growing process. ${ }^{(2,7)}$ Recurrence is common in soft tissue RDD without lymph node involvement, as exemplified in the study in which $7(54 \%)$ of the 13 patients presented tumor recurrence after local excision. ${ }^{(3)}$ Whenever feasible, the excision should be performed with wide surgical margins, ${ }^{(2,3)}$ since chemotherapy has not proven useful. ${ }^{(3,8)}$ Our patient was submitted to a diagnostic surgical intervention in which the excision was made with extended margins. No additional treatment was initiated, and the patient remained disease-free for the following 12 months.

The patient history of an episode of cervical pain and lymphadenomegaly 12 months prior to the identification of the posterior mediastinal mass, together with the fact that the cervical pain and lymphadenomegaly resolved spontaneously, was suggestive of typical nodal RDD. No biopsy or other specific investigation was performed. Therefore, one could speculate that the isolated soft tissue RDD in the present case represented the residual involvement of a more typical condition. Indeed, the para-aortic lymph node affected by RDD suggested residual lymph node involvement. This presentation of the disease (partial remission, remaining as a solitary soft tissue mass) has not been previously reported. However, it is possible that many cases of soft tissue RDD involved previous episodes of mild self-resolving cervical lymphadenopathy which were not reported in the clinical histories.

Posterior mediastinal tumors comprise a large spectrum of rare conditions, the most common of which are lymphomas and neurogenic tumors. ${ }^{(9)}$ Hodgkin's lymphoma is the most common lymphoma affecting the mediastinum. Neurogenic tumors fall into two major categories: neoplasms of the sympathetic nervous 
system (neuroblastomas, ganglioneuroblastomas and ganglioneuromas); and peripheral nerve sheath tumors (schwannomas, neurofibromas and malignant peripheral nerve sheath tumors). ${ }^{(10)}$ Histologically, RDD and Hodgkin's lymphoma can present certain overlapping features, the latter occasionally presenting an inflammatory appearance and large neoplastic cells resembling large histiocytes. However, the two entities can easily be distinguished through careful examination of the infiltrate, identification of unequivocal images of emperipolesis in RDD, identification of neoplastic ReedStenberg cells in Hodgkin's lymphoma and immunophenotyping.

The initial workup of a suspected mediastinal mass involves obtaining anteroposterior and lateral chest X-rays, which can provide information pertaining to the size, anatomic location and density of the mass. In addition, CT scans can further characterize mediastinal masses and their relationship to surrounding structures, as well as identifying cystic, vascular and soft tissue structures. Other methods, including fluoroscopy, barium swallow, angiography, CT angiography and three-dimensional reconstruction, can provide additional information. Magnetic resonance imaging is also valuable when it is necessary to investigate the invasion of large vessels or cardiac involvement. Newer methods can also be used to better investigate posterior mediastinal masses. Endoscopic and endobronchial ultrasound are safe procedures that can allow the relationship between the tumor and the major surrounding structures to be analyzed, as well as facilitating biopsy. ${ }^{(9,11)}$
The present case highlights the importance of including extranodal RDD in the differential diagnosis of inflammatory and fibrohistiocytic soft tissue lesions. This is the first report of soft tissue RDD in the posterior mediastinum.

\section{References}

1. Rosai J. Lymph nodes. In: Rosai J, Ackerman LV, editors. Rosai and Ackerman's Surgical Pathology. New York: Mosby; 2004. p. 1911-13.

2. Foucar E, Rosai J, Dorfman R. Sinus histiocytosis with massive lymphadenopathy (Rosai-Dorfman disease): review of the entity. Semin Diagn Pathol. 1990;7(1):19-73.

3. Montgomery EA, Meis JM, Frizzera G. RosaiDorfman disease of soft tissue. Am J Surg Pathol. 1992;16(2):122-9.

4. Lim R, Wittram C, Ferry JA, Shepard JA. FDG PET of Rosai-Dorfman disease of the thymus. AJR Am J Roentgenol. 2004;182(2):514.

5. Choe JW, Oh TY, Cho EY, Chang WH. Extranodal RosaiDorfman Disease in Mediastinum: A Case Report. Korean J Thorac Cardiovasc Surg. 2002;35(10):768-72.

6. Friedman MJ, Rossoff LJ, Aftalion B, Khan A, Decker $\mathrm{R}$, Steinberg $\mathrm{H}$. Sinus histiocytosis presenting as a mediastinal mass. Chest. 1984;86(2):266-7.

7. Veinot JP, Eidus L, Jabi M. Soft tissue Rosai Dorfman disease mimicking inflammatory pseudotumor: a diagnostic pitfall. Pathology. 1998;30(1):14-6.

8. Zannolli R, Acquaviva A, Polito E, Galluzzi P, Ferrari $\mathrm{F}$, Leoncini L, et al. Pathological case of the month. Multifocal Rosai-Dorfman disease of soft tissue. Arch Pediatr Adolesc Med. 1999;153(11):1199-200.

9. Strollo DC, Rosado-de-Christenson ML, Jett JR. Primary mediastinal tumors: part 11. Tumors of the middle and posterior mediastinum. Chest. 1997;112(5):1344-57.

10. Rosai J. Mediastinum. In: Rosai J, Ackerman LV, editors. Rosai and Ackerman's Surgical Pathology. New York: Mosby; 2004. p. 459-513.

11. Duwe BV, Sterman DH, Musani Al. Tumors of the mediastinum. Chest. 2005;128(4):2893-909.

\section{About the authors}

\section{Antônio Luiz Penna Costa}

Thoracic Surgeon. Hospital Espanhol, Federal University of Bahia, Salvador, Brazil.

\section{Natália Oliveira e Silva}

Medical Student. Bahia School of Medicine and Public Health, Salvador, Brazil.

\section{Marina Pamponet Motta}

Medical Student. Bahia School of Medicine and Public Health, Salvador, Brazil.

\section{Rodrigo Abensur Athanazio}

Resident in Pulmonology. University of São Paulo School of Medicine Hospital das Clínicas, São Paulo, Brazil.

\section{Daniel Abensur Athanazio}

Assistant Professor in Human Pathology. Federal University of Bahia, Salvador, Brazil.

\section{Paulo Roberto Fontes Athanazio}

Adjunct Professor in the Departament of Pathological Anatomy and Legal Medicine. Federal University of Bahia, Salvador, Brazil. 